\title{
Using Ecological Footprint Accounting model as a tool for sustainable development in the hospitality industry: Evidence from Egypt
}

\author{
Mohamed Samy El-Deeb \\ Associate professor of accounting \\ Faculty of Management Sciences \\ Modern Sciences and Arts University \\ msamy@msa.eun.eg \\ Yasser Tawfik Halim \\ Professor of Marketing \\ Faculty of Management Sciences \\ Modern Sciences and Arts University \\ ytawfik@msa.eun.eg
}

\begin{abstract}
In recent years, the trend toward the sustainability reports are increasing especially within the era of the integrating reporting. In the same time the efforts of the government for improving the hospitality sector represented in the tourism industry in Egypt is one of the main objectives of 2030 plan. The impacts of the hospitality industry on the environment have become widely acknowledged. As tourism is predicted to continue growing in the next decade, there is an urgent need for the hospitality sector to embrace sustainability principles in order that tourists may continue travelling, while placing minimal impacts on the natural environment. Although there is much debate over the concepts of sustainability and how it is to be measured, the Ecological Footprint has recently been proposed as a key indicator of sustainable hospitality activities, due to its abilities to quantify the amount of resources needed for hospitality activities, and enable comparisons between hospitality components through its global, standardized measurements. The Ecological Footprint is a tool that measures humanity's demands upon the natural biosphere and its effect on the national resources of the countries.
\end{abstract}


It tracks the biologically productive land and water required to produce all the resources a population consumes and to segregate its wastes.

Information was collected on respondents from hotels managers and they requested to provide information on accommodation aspects such as occupancy rates, property sizes, average water and energy usage, waste management routines and information to determine the average ecological footprints of tourists in the selected hotels. In order to understand the relationship between the ecological footprint and tourist behaviors. The analysis of this information provide an indication of the current green status of hospitality and for better environmental practices.

\section{SCOPE OF THE RESEARCH PRESENTATION:}

This study attempts to find ways to achieve an acceptable balance between the sustainable developments of the hospitality industry in Egypt by increasing the profitability of the hotels without hurting the environmental resources using Ecological footprint method. It also attempts to outline effective plan that aims to increase the elements of environment conservation within the hospitality industry. This study is coping with the general trend of the government to maintain the sustainability in all fields of activities. The proposed set of policies take into consideration the integrity of hospitality services, the criteria of environmental quality, and all of the necessary aspects needed to achieve a sustainable development in this valuable industry. Tourists tend to travel and use water, energy, and produce solid wastes. It also attempts to outline effective policies, strategies, plans, and programs that aim to integrate the elements of environmental conservation within managing the hospitality industry.

Many of International organizations around the world have been calling attention to the negative influence of hospitality activities on natural environmental resources, negative economic impact, as well as social and cultural beliefs and features. It is widely held view that as the world has got richer, so it has got more polluted. However, the industry development is growing noticeably in spite of its negative environmental aspects especially economical ones. This indeed, requires an environmental management policy with specific objectives, a welldefined strategy that can be put into action plans include specific set of 
programs to deal with the environmental conservation and pollution issues and that can be measured on regular intervals to determine their effectiveness, to assess damages and revise any mistakes, which might lead to destructive effects.

There are some facts that hospitality professionals should consider, among these are traditional systems are no longer effective; environmental quality system should be designed to satisfy tourists' needs and expectation; top management commitment to environmental quality management as a profit center; availability of equipment and availability of financial resources. It provides a useful means of quantifying environmental impacts as well as identifying opportunities for cost savings.

This paper will focus on Ecological footprint as a tool for assessing sustainability of the Egyptian hospitality sector and the impact of the proposed measures on the performance of hospitality industry in Egypt.

\section{RESEARCH LIMITATIONS}

The results of the research based on a limited survey that were distributed on number of hotels of Great Cairo region for a limited budget and time limitation. Our research participants are International chains of 5 star hotels managers operating in Egypt as we hypothesize that they are much more deliberate for keeping record better than other hotels categories managers, and it is recognized that further research is necessary to establish the exact nature of the causal linkages between the ecological footprint accounting proposed model and the sustainability assurance for the whole categories of the Egyptian hospitality industry, to gain insights and be able to generalize the results.

\section{KEY WORDS}

Ecological footprint, Hospitality industry, Sustainable development 


\section{LITURATURE REVIEW:}

Reviewing literature revealed a gap with regard to the impact of managing environmental conservation on the hospitality sector resources and performance. Therefore, this research study is a significant contribution to knowledge as it covers the above stated gap.

As a result of the arguments between the researchers upon the relation between the economic impact of using the environmental activities and the sustainability of the companies, many researchers started to stress more in their writings on the responsibility of the organizations for the sustainability of the society. (O'Dwyer and Owen, 2005; Mock et al., 2013; Claire Gillet-Monjarret, 2018). The concept of sustainability had been the trend among all the corporate governance writes during the past 10 years. Another important concept that had emerged also is the corporate accountability for the sustainability of the society as a whole. This led the organizations to include their social and environmental activities in a separate report like the CSR reports and the integrated reports to face the demands for information from the stockholders. Ecological Footprint is a practical tool that enables hotels to calculate the environmental impact that a hotel products have on the environment in terms of resources used. It also gives an estimate of the relative environmental sustainability of a product, and helps to identify opportunities for footprint reduction and cost savings (Maroun, Atkins, 2018).

\section{The environmental impacts of tourists' activities}

Tourist activities could hurt the environment from different ways, whether through soil destruction, the interruption of wildlife behaviors, coral reef damage or the excessive use of energy and resources (Almeida-Neto, et al., 2008). As tourists try to keep their consumption level at holiday similar to their consumption at home countries, even for places that are not well equipped to handle the possibly damaging effects of mass hospitality activities, which could be a problem for those touristic areas (Welford et al., 1999). In the case of Caribbean cruise tourism, environmental impacts occur through pollution, coral reef destruction, and the deliberate dumping of waste oil and chemicals. Furthermore, the 
average cruise tourist generates $1 \mathrm{~kg}$ of burnable waste, $0.5 \mathrm{~kg}$ of food waste and $1 \mathrm{~kg}$ of glass and caddy waste per day for disposal (Hart, et al., 2002). Although these types of hospitality activities impacts are often visible at a destination, and can possibly be more damaging especially in the case of air travel because it is responsible for greenhouse gases which is the main reason for global warming (Gössling, et al., 2002). The alarming fact about these impacts is that hospitality activities are continually growing and developing. For instance, the World Tourism Organization predicts that the number of worldwide tourists will increase from 720 million in 2004 to 1.6 billion by 2020 (Murphy, Price, 2005). Consequently, of these predictions, there is a definite need to reduce the impacts of hospitality activities, while permitting countries to remain benefiting economically from hospitality money (Böhler et al., 2006).

\section{Sustainable development in the hospitality industry}

The World Commission on Environment and Development introduced the concept of sustainable development. It was defined broadly as:

"development that meets the needs of the present, without compromising the ability of future generations to meet their own needs".

The term has criticized by many scientist, it also recognized as sustainability because of its unclear implications. They thought that due to its ambiguity they poorly used as a worthless marketing tool (Lele, 1991).

"criteria for sustainability should include not only environmental stability and improvement, but social, political and economic justice, improvement in the quality of life and in the overall status" (Parayil, 1996).

Natural capital whether it is renewable or non-renewable is affecting dramatically the ability of the company in generating profit and by default its sustainability in the economy (Toth, Szigeti, 2016). one of the major nonrenewable resources is the energy. The energy culture framework is allowing a better understanding of the behavior of the organizations in consuming the energy as nonrenewable resources and its effect on the sustainability of the organization from both perspectives financially and non-finically (Rotzek, Scope and Günther, 2018). 
A strong sustainability scenario would result in natural capital stocks being conserved and enhanced. Contrarily, weak sustainability occurs when losses of natural capital can be substituted through equivalent amounts or value of human-made materials. In the long term however, weak sustainability is not viable, as manufactured products often require natural capital as a prerequisite (Rees, Wackernagel, 1996).

The sustainability reports of the companies are designed to capture all the different components of the sustainability measures like the corporate water accounting tools and methodologies. In this research the researcher focused on the water as a new topic in the literature of accounting as a renewable natural capital and it developed a framework to report about the corporate water accounting (Gibassier, 2018).

The realization of hospitality activities negative impacts occurred simultaneously with the rise of environmentalism in the mid to late 1980's, which combined, resulted in the reassessment of hospitality role and value at destinations (Toth, Szigeti, 2016). According to Rees, Wackernagel, (1996):

"Sustainable tourism development meets the needs of present tourists and host regions while protecting and enhancing opportunity for the future. It is envisaged as leading to management of all resources in such a way that economic, social and aesthetic needs can be fulfilled while maintaining cultural integrity, essential ecological processes, biological diversity and life support systems".

Sustainable hospitality activities are believed to be more accepted in newly discovered areas where regular activities may be seen negatively, and it may be the only path that will enable a community to develop while minimizing impacts on the environment (Genovart, et al., 2016). other researches reinforced this idea by defining sustainable hospitality activities as "a positive approach intended to reduce the tensions and friction created by the complex interactions between the hospitality industry, visitors, the environment and the communities which are host to holidaymakers". (Budeanu, et al., 2016). Pezzey, et al., (1990) believe there are three main ways that can assist a destination in becoming sustainable. The first is through using Eco-techniques, which includes behaviors such as harvesting solar energy, collecting rainwater, recycling and using local materials. These techniques can be very significant in 
terms of sustaining and enhancing the quality of a destination's physical environment. The second method of attaining sustainability is through environmental sponsorship. This entails making a commitment to the environment, and communities in which hotels and resorts operate. Examples include tree planting, creating conservation programs for local schools, fundraising for threatened species, or allotting an area for an environmental preserve. Lastly, sustainability can be achieved through eco-packaging in which hotels and resorts can offer guests environmentally oriented activities such as wildlife viewing.

As expected with the confusion surrounding sustainable development, achieving sustainable hospitality activities has been, and continues to be a difficult challenge. According to Sigee et al., (1999) tourism researchers and policy-makers responded relatively slowly to sustainable development's concepts, and although progress has been made, many remain on the sidelines, while the debate continues on sustainability's definition and implications. Without a doubt, hospitality activities use natural resources and therefore places significant impacts on the environment. A joining of hospitality activities and sustainability concepts therefore seems like a natural move, however many questions arise regarding the validity of sustainable hospitality activities, how it can be achieved and how one knows when it has been achieved. Diamantis, Ladkin, (1999) studied British hospitality business owners were unclear about the meaning of sustainable hospitality activities and it was to be implemented into their businesses. Many owners felt that they were already being sustainable in their work, since they were not offering activities that were environmentally damaging.

As in sustainable development, there is the argument of whether sustainable hospitality activities at a destination should entail weak or strong interpretations. Weak sustainable hospitality activities would involve continued economic growth, maintenance of adequate environmental quality and the continued use of current or future hospitality products and locations. In contrast, strong sustainable hospitality activities revolve around protecting the natural resources that support hospitality activities, rather than supporting economic growth at the possible expense of the environment (Hunter, 2002). Of course, as social needs are a primary consideration, it must also be asked whether 
sustainable hospitality activities are useful to communities, or if it is just another popular term intended to gain the interest and money of tourists looking for meaningful holidays (Martin, 1997). The answer remains unclear, and may depend on the characteristics of, and available resources in each tourist destination. As Sigee, et al., (1999) states, "sustainable development is neither always possible, nor even always appropriate in the context of tourism". As such, the debate will continue on whether hospitality can exist as an economic and development tool, while ensuring environmental and social sustainability in tourist destinations.

\section{Measuring sustainable performance in hospitality industry}

Measurement of the sustainability performance is becoming more relevant for all the organization as it is considered as an integral part of the accounting for sustainability and the sustainability management system for the organizations. The main question here is how to determine the stakeholder's expectations for the measurement of the sustainability performance and what are the effect of that measurement on the continuity of the organizations in the business (Samanthi Silva, Edeltraud Guenther, 2018).

Since the concept of sustainability includes economic, social and environmental aspects, several measures encompassing these areas are needed to measure hospitality activities impact on the environment. Social and economic sustainability can be partly measured through the United Nations Human Development Index, which provides an indication of the overall well-being of a population, through measuring life expectancy, education and income (Ozturk et al., 2016).

In contrast, the environmental sustainability of an area can be indicated through measuring its carrying capacity, defined as the "number of individuals of a given species that a given habitat can support without being permanently damaged" (Fernández, et al., 2016). Unfortunately, there are two weaknesses associated with the carrying capacity theory. Firstly, the total ecological load of a population will vary according to income, technology level and their expected standard of living, and secondly, people need resources that the carrying capacity of that specific area may not be able to provide (Hunter, Shaw, 2007). Other 
environmental sustainability indicators include the limits of acceptable change system and the environmental impact assessment, although both of these indicators focus on the local environment and ignore the larger global consequences of travel, particularly in the transit phase (Gössling, et al., 2002). Although no indicator exists for the sole purpose of measuring environmental sustainability in a hospitality context, promise appears to lie with the ecological footprint tool which takes into account the transit phases, provides impacts at a global level and above all, can be adjusted to address hospitality scenarios (Hunter, Shaw, 2007).

\section{The ecological footprint concept}

A measure of the area of biologically productive land and water an individual population or activity requires to produce all the resources it consumes and to sequester its waste. Both ecological footprint and biocapacity results are expressed in a globally comparable, standardized unit called a "global hectare" - a hectare of biologically productive land or sea area with world average bio-productivity in a given year (Fernández, et al., 2016).

The ecological footprint is a relatively new concept, and it appears that only a few studies have used this tool to measure hospitality activities impact; two of which involved sun-seeking tourists on package holidays (Gössling, et al., 2002) and one which focused on ecological footprint differences between tourists and a host population (Patterson, Niccolucci $\&$ Bastianoni, 2007). As such, limited research has been completed on the ecological footprint as it relates to hospitality sustainability.

The ecological footprint is an accounting tool used to measure mankind's demand for the regenerative capacity of our planet: Earth's bio-capacity. Human demand for bio-capacity is determined by adding up all demands placed on the productive surfaces of the planet. (Budeanu, et al., 2016; Cerutti, et al., 2016).

The ecological footprint (EF) is an area-based indicator that measures the intensity by which humans use resources and generate waste, relative to that area's capacity to provide for these activities. It is also referred to an 'appropriated carrying capacity' since every person appropriates the 
productive capacity of nature. Ecological footprint calculations take into account the land and water supplies needed to produce food, fiber and timber for consuming, absorbing waste generated by energy, and providing space for infrastructure. A world-average ability to produce resources and absorb wastes, required to support the life and activities of one individual (Wackernagel, Yount, 2000).

As ecological footprints vary across the world, countries can be categorized as ecological debtors, meaning their EF is greater than the bio-capacity they produce, or they can be creditors whose bio-capacity is greater than their ecological footprint. The United States and the United Kingdom are both ecological debtors with footprints that are 50\% larger than the amount of resources each country can produce. In order to maintain these high footprints, countries in this situation can deplete their natural capital, import resources from other countries or generate more waste than their ecosystems can absorb. Canada, on the other hand, even with a large ecological footprint, is considered a creditor as it possesses a biocapacity which is over $50 \%$ larger than its footprint. As such, its bioproductive land can relatively easily support its population's level of consumption, however continuing with such high ecological footprints would not result in the achievement of sustainability targets, since one's footprint space cannot be shared (Rees, Wackernagel, 1996).

\section{Benefits and limitations of the ecological footprint in the hospitality industry}

The ecological footprint has recently been proposed as a key indicator for measuring the environmental impacts of tourists' activities (Hunter, Shaw, 2007). Unlike other locally based measures, such as carrying capacity or environmental impact assessments, the ecological footprint takes into account the consequences of transit as it relates to touristic activities. (Hunter, Shaw, 2007). As a result of these characteristics, Wackernagel, Yount (2000) were able to use the EF tool to prove that current levels of global resource consumption and waste generation were greater than the biosphere's biotically productive area. In a hospitality context, were also able to determine that at least $10 \%$ of the world's ecological footprint was occupied by the hospitality industry's international component. 
Unlike other indicators, the EF does not assume that ecological productivity can be continually replaced with technological advances, therefore it highlights the issues that could arise when substitutes are no longer available (Senbel, McDaniels \& Dowlatabadi, 2003). Furthermore, the EF can be calculated for specific components of a lifestyle, for entire nations or for business activities, and is therefore a flexible and versatile indicator. The common unit of measurement allows the 'ecological accounts' of these different components to be compared in terms of their impacts on the environment, in order to determine their level of sustainability and discover more eco-friendly alternatives (Wackernagel, Yount, 2000; Holland, 2003).

Although a promising tool, the Ecological Footprint has limitations and as such, its calculations cannot derive completely accurate values. Part of its limitations lie in that fact that knowledge is still developing on the potential of this indicator. As a result, there are several fundamental assumptions that must be taken into account, in order to provide understand the foundation for Ecological Footprint calculations (Cartamil, et al., 2003):

1. The resources people consume and the wastes they generate can be tracked.

2. Most of these resource and waste flows can be measured in terms of the biologically productive area necessary to maintain these flows.

3. Resource and waste flows that cannot be measured are excluded from the assessment, leading to a systematic underestimate of the true Ecological Footprint.

4. Human demand, expressed as the Ecological Footprint, can be directly compared to nature's supply (bio-capacity).

5. Area demand can exceed area supply if demand on an ecosystem exceeds that ecosystem's regenerative capacity. This situation, where Ecological Footprint exceeds available biocapacity, is known as overshoot.

Currently, the largest weakness of the EF as a sustainability indicator is its inability to measure socio-economic factors, resulting in its need to be 
combined with other indicators in order to determine the overall sustainability of a lifestyle or activity (Hunter, Shaw, 2007). Since, the EF relates environmental consequences to the global biosphere, it also cannot assist in the understanding of local impacts (Gössling et al., 2002). Furthermore, EF calculations require detailed information on consumption and biomass yield figures, which can be difficult to obtain when statistical databases are incomplete.

Clearly, although carrying a number of positive features, the limitations surrounding the ecological footprint enable it to only provide a rough indication of sustainability levels. These limitations appear to be well known and accepted by ecological footprint advocates. Rees (2000) states that "ecological footprint analysis was not intended to provide a dynamic window on the future, but rather a snapshot in time. As such it can both help to assess current reality and to test alternative 'what if' scenarios on the road to sustainability".

\section{Ecological footprint as a sustainability measurement tool for hospitality industry}

Hunter, (2002) mentioned that the use of the ecological footprint as a tool for measuring the sustainability of hospitality activities is a new concept, and one that is not very straightforward given hospitality diversity in transportation, food and accommodation components. However, the EF of these individual hospitality components, can be calculated and summed to produce an approximate hospitality ecological footprint. These footprints, should in theory, indicate which types of hospitality activities are and are not sustainable, in order to assist decision and policy makers in developing hospitality regulations (Wackernagel, Yount, 2000). As a new concept, it appears that relatively few researchers have attempted to integrate the ecological footprint into hospitality scenarios, however, among a few others; this has been successfully completed by (Gössling et al., 2002; Patterson, Niccolucci, Bastianoni, 2007).

Ecological footprint in hospitality scenarios is still a new concept, however it shows a promising ability to indicate the global impacts of hospitality activities and, in particular, the immense consequences of hospitality-related transportation. However, there is still much research to 
be completed to determine the resource requirements and sustainability levels of different types of hospitality activities. Footprint promotes the science of sustainability by advancing the Ecological Footprint, a resource accounting tool that makes sustainability measurable. Together with its partners, the Network works to further improve and implement this science by coordinating research, developing methodological standards, and providing decision-makers with robust resource accounts to help the human economy operate within the Earth's ecological limits (Fortier, Messier, 2006).

This initiative also blends beautifully into the Accor Group's new aim, which it has encapsulated in its new Open New Frontiers in Hospitality claim. It claimed by the authors that they are innovating, inventing new approaches to break down barriers and imagining hospitality tomorrow. It was claimed also, that they are driving towards $360^{\circ}$ hospitality, combining comfort, wellness and environment-friendliness. That is inherent to the Group's strategy to build ever more inviting - and smart hotels (Melissen, et al., 2016).

This study was set out to assess the Group's impacts on the environment - and aims high. It looks at the full picture, not just co2 emissions: it encompasses the Group's annual impacts in terms of energy, water consumption and contamination, and waste. And it looks way beyond Accor hotels, at the indirect impacts that they generate for example in the farms that raise the poultry they serve in their restaurants and from the trucks that transport it between the two (Melissen, et al., 2016).

\section{Accounting for the ecological footprint in the hospitality industry}

The Ecological Footprint is a well-known resource accounting tool that measures how much biologically productive land and water area an individual, a city, a country, a region, or humanity uses to produce the resources it consumes and to absorb the waste it generates, using prevailing technology and resource management (Rees, Wackernagel, 1996). The Ecological Footprint is most commonly expressed in units of global hectares. A global hectare is a hectare that is normalized to have the world average productivity of all biologically productive land and water in a given year. Because of international trade and the dispersion of 
wastes, hectares demanded can be physically located anywhere in the world. (Wackernagel, et al., 1999)

To date, Switzerland has completed a review, while Belgium, Ecuador, the European Commission, Finland, France, Germany, Indonesia, Ireland, Japan, Luxembourg and the United Arab Emirates have partially reviewed or are reviewing their accounts. A formal review committee oversees the continuing methodological development of the National Footprint Accounts. There is growing recognition of the need to standardize sub-national Footprint applications in order to increase comparability across studies and time periods. Methods and approaches for calculating the Footprint of municipalities, organizations and products are being aligned through a global Ecological Footprint standards initiative (Nakajima, Ortega, 2016).

The predominant focus in natural capital accounting is on integrating environmental information into standard economic accounts. However, also of interest is the potential to glean information from standard economic accounts about activities undertaken by economic units that may be considered "environmental" (Ahmad, et al., 1989).

To this end, the SEEA Central Framework defines the environmental activities of environmental protection and resource management as constituting a scope that can be used to classify various standard economic flows such as output, value added, investment and employment. The SEEA Central Framework defines environmental protection expenditure accounts to record expenditures by governments, households and businesses that have the purpose of maintaining or improving the environment. The SEEA Central Framework also defines the Environmental Goods and Services Sector and an associated set of indicators that may be used to provide ongoing estimates of output and employment in environmental activities as a share of overall economic activity (Bebbington, Larrinaga, 2014).

To further aid assessment of the policy response to environmental issues, this area of accounting provides definitions for environmental taxes and environmental subsidies and similar transfers. Particularly at an 
international level, consistent definition of these types of variables permits an assessment of alternative policy responses (Galli, 2015).

\section{Fundamental Assumptions of Ecological Footprint Accounting}

Ecological Footprint accounting is based on a fundamental assumption (Wackernagel et al., 2002):

"The majority of the resources people consume and the wastes they generate can be tracked. Most of these resource and waste flows can be measured in terms of the biologically productive area necessary to maintain flows".

Resource and waste flows that cannot be measured were excluded from the assessment, leading to a systematic underestimate of humanity's true Ecological Footprint. By weighting each area in proportion to its bioproductivity, different types of areas can be converted into the common unit of global hectares, hectares with world average bio-productivity. Because a single global hectare represents a single use, and all global hectares in any single year represent the same amount of bio-productivity, they can be added up to obtain an aggregate indicator of Ecological Footprint or biocapacity (Coscieme et al., 2016).

Human demand, expressed as the Ecological Footprint, can be directly compared to nature's supply, biocapacity, when both are expressed in global hectares. Area demanded can exceed area supplied if demand on an ecosystem exceeds that ecosystems regenerative capacity (e.g., humans can temporarily demand more biocapacity from forests, or fisheries, than those ecosystems have available). This situation, where Ecological Footprint exceeds available biocapacity, is known as overshoot (Koocheki, et al., 2016).

Although the goal of Ecological Footprint accounting is to measure human demand on the biosphere as accurately as possible, the methodology is designed to underestimate human demand on the biosphere where uncertainty exists. Because the Footprint is a historical account, many activities that systematically erode nature's future regenerative capacity are not included in current and past Ecological Footprint accounts. These activities include the release of materials for which the biosphere has no significant assimilation capacity (e.g. 
plutonium, PCBs, dioxins, and other persistent pollutants) and processes that damage the biosphere's future capacity (e.g., loss of biodiversity, salination resulting from cropland irrigation, soil erosion from tilling). Although the consequences of these activities will be reflected in future Ecological Footprint accounts as a decrease in biocapacity, Ecological Footprint accounting does not currently include risk assessment models that could allow a present accounting of these future damages (Kitzes, et al., 2009).

Similarly, Ecological Footprint accounts do not directly account for freshwater use and availability, since freshwater acts as a limit on the amount of biological capacity in an area but is not itself a biologically produced good or service. Although the loss of biocapacity associated with water appropriation or water quality degradation is reflected as a decrease in overall biocapacity in that year, an ecological footprint of its use is not currently allocated to the consumer of the water resource (Koocheki, et al., 2016).

Hospitality activities are currently attributed to the country in which they occur rather than to the traveler's country of origin. This distorts the relative size of some countries' Footprints, overestimating those that host tourists and underestimating the home countries of travelers. Current data constraints also prevent the Footprint associated with the generation of internationally-traded electricity from being allocated to the final consumer of this energy. These two limitations affect the allocation of Ecological Footprint between nations but not the total global Footprint. The demand on biocapacity resulting from mission of greenhouse gases other than carbon dioxide is not currently included in Ecological Footprint accounts. Incomplete scientific knowledge about the fate of greenhouse gases other than carbon dioxide makes it difficult to estimate the biocapacity required to neutralize their climate change potential (Kasim, 2015).

\section{RESEARCH METHODOLOGY:}

In order to provide a comprehensive study, the researchers referred to a large number of textbooks, periodicals and online databases. Overall, previous literature reviews in this area imply that there is a gap in the 
literature pertaining to enhancing the environmental performance by decreasing the Ecological Footprint in the Egyptian five star hotels. Reviewing literature was helped in formulating the research questions and identifies the existing gap in the literature.

The problems that face most of the Egyptian hotels are how to enhance sustainable development. This can be achieved through relating Ecological footprint accounting model with the performance of the hospitality industry in Egypt. Therefore, it was crucial to examine first, how to integrate the Ecological footprint accounting model with the three pillars of sustainable development in Egyptian five star hotels, second, how to measure financial performance of the hospitality industry in Egypt based on the Ecological Footprint proposed model.

A methodology was considered to be appropriate in view of the nature of the data to be collected and the knowledge about environmental conservation in Egyptian hospitality Industry. Moreover, reviewing literature provided a valuable insight as to which of the materials and methods could be most appropriate to collect reliable data from hospitality industry in question. The questionnaire is a more appropriate instrument for gathering large amount of data from the sample selected than other data collection methods.

A pilot study was conducted on one of the five star hotels to test the data collection instrument and examine the efficiency and effectiveness of the methodology selected to achieve the objectives of this research study. In addition, a wide-ranging and vigorous fieldwork was conducted; covering 10 luxurious five-star hotels was randomly selected in Great Cairo region. The research was targeting 120 managers.

\section{RESEARCH OBJECTIVES:}

1. To integrate the Ecological footprint accounting model with the three pillars of sustainable development in Egyptian five star hotels.

2. To measure the financial performance of the hospitality industry in Egypt based on the Ecological Footprint accounting proposed model. 


\section{RESEARCH HYPOTHESES:}

1. The integration of Ecological footprint accounting model has a positive association with the three pillars of sustainable development in the Egyptian five star hotels.

2. The Ecological footprint accounting proposed model enhances the financial performance of the hospitality industry in Egypt.

\section{Data collection instruments}

Primary data were collected using structured questionnaires, targeting managers from all departments. The questionnaire was composed of 3 clusters (Social, Environmental, Economic/Financial) of questions that cover the efficient use, consume and dispose of Water, Energy and SolidWastes at the following areas:

- Water:

○ Questions covering to what extent the hotel use tap water in the daily activities. How to measure water quality by Health Safety Environment (HSE) programs and how it affects organizational activities. What is the most efficient methods to reduce water pollution (reuse, recycle....) and to rationalize the use of water. Calculating the cost of tap water and the cost of wastewater disposal and measuring the effect on the cost of product and service provided to customer. Also, the effects on organizational profitability. Determining the cost of water quality enhancement and its effects on organizational profitability (filtering, treatment, etc.). and finally assessing the cost of water treatments and its effect on organizational profitability.

- Energy

- Questions covering to what extent the hotel use the source of electricity in all working activities for serving guests (cooking, heating, lighting, and transportation). Questioning the other sources of energy rather than electricity in working activities (natural gas, gasoline coal...etc). Determining the different 
techniques to decrease the volume of energy used. How to measure the effectiveness of some of renewable resources of energy come from (solar, wind, others) used by the organization. Assessing how energy cost (electricity, natural gas, other) affect the (cost) of product and service. Finally, evaluating the cost of energy conservation program and its effect on the cost of product and service

- Solid wastes

- Questions covering to what extent the hotel measure the volume of solid waste generated by employees and guest affects daily activates. How to use the effective program to reduce the volume of solid waste (ISO 14001). Determining ways of segregate solid waste at the source and its effect on the hotel. Assessing the cost of disposing and recycling solid wastes effect on the organization profitability. Finally, expecting the ecological footprint impact to enhance the financial profitability ratios (ROI, ROA, ROE.... etc)

\section{Sample size}

The sample was selected from 10 five-star hotels in Greater Cairo were participating in the study, hotels totally declined exposing their names in the study. The hotels were selected from the international chains operating in Egypt.

Three stages clustering sample is a non-probability sampling method that is based on: first selecting 2 governorates (Cairo and Giza (Greater Cairo)) from the 27 Egyptian governorates. Second selecting samples from hotels that represent the number of international chains in the selected governorates. Third, randomly distribute the questionnaire forms to the minimum number of employees who represent each hotel. In this case, 15 forms were distributed to the three hierarchical levels (senior, middle, and first line managers). In addition, this sampling technique reduces cost and time in preparing the sample. 150 forms were distributed to managers of the all departments in the hotels under investigation. However, 107 valid filled in questionnaire forms were received from the three managerial hierarchical levels. Therefore, the response rate is 71.33 
\% which is statistically acceptable for data analysis. Data obtained was analyzed by using the Statistical Package for Social Sciences (SPSS). Combinations of different techniques were used including: reliability, intrinsic validity and logistic regression model.

\section{THE PROPOSED MODEL:}

The proposed model has three folds environmental, social and economic/financial. The overall objective is to provide hospitality managers with new analytical and comprehensive tool to help them overcome the current socio-economic and environmental challenges for overcome and reduce the damages happened by the tourists in the environment. The proposed model is visually represented in table (1). The model was designed using the views and opinions of hospitality properties' decision makers, professionals, hotel management, environment and economic professors.

The following table includes the measures proposed by the researchers for measuring the effect of the ecological footprint and the sustainable development on the environmental and financial performance of the five star hotels.

Table (1): proposed social, environmental and financial measures for sustainability development in hospitability industry

\begin{tabular}{|c|c|}
\hline Components & Data Required \\
\hline \multirow{5}{*}{ Social } & $\begin{array}{l}\text { (Water) Employees using tap water in their daily activities for } \\
\text { serving guests }\end{array}$ \\
\hline & $\begin{array}{l}\text { (Water) Health Safety Environment (HSE) programs for } \\
\text { measuring water quality (affect the activities of organization) }\end{array}$ \\
\hline & $\begin{array}{l}\text { (Energy) Employees using only electricity in all working } \\
\text { activities for serving guests (cooking, heating, lighting, and } \\
\text { transportation) }\end{array}$ \\
\hline & $\begin{array}{l}\text { (Energy) Employees using other sources of energy rather than } \\
\text { electricity in working activities (natural gas, gasoline, } \\
\text { coal...etc) }\end{array}$ \\
\hline & $\begin{array}{l}\text { (Solid wastes) Volume of solid waste generated by employees } \\
\text { and guest affects daily activates }\end{array}$ \\
\hline & \\
\hline \multirow{2}{*}{ Environmental } & $\begin{array}{l}\text { (Water) The organization using efficient methods to reduce } \\
\text { water pollution (reuse, recycle....) }\end{array}$ \\
\hline & $\begin{array}{l}\text { (Water) The organization using efficient methods to rationalize } \\
\text { the use of water }\end{array}$ \\
\hline
\end{tabular}




\begin{tabular}{|c|c|}
\hline & $\begin{array}{l}\text { (Energy) The organization using different techniques to } \\
\text { decrease the volume of energy used }\end{array}$ \\
\hline & $\begin{array}{l}\text { (Energy) Some of the energy used by the organization come } \\
\text { from renewable resources (solar, wind, others) }\end{array}$ \\
\hline & $\begin{array}{l}\text { (Solid wastes) The organization using effective program to } \\
\text { reduce the volume of solid waste (ISO 14001) }\end{array}$ \\
\hline & $\begin{array}{l}\text { (Solid wastes) The organization segregates the solid waste at the } \\
\text { source }\end{array}$ \\
\hline \multirow{8}{*}{ Economic/Financial. } & $\begin{array}{l}\text { (Water) Tap water cost affects the cost of product and service } \\
\text { provided to customer. }\end{array}$ \\
\hline & (Water) The cost of wastewater disposal affects profitability. \\
\hline & (Water) The cost of water treatments affects profitability \\
\hline & $\begin{array}{l}\text { (Water) The cost of water quality enhancement affects } \\
\text { profitability, (filtering, treatment, etc.). }\end{array}$ \\
\hline & $\begin{array}{l}\text { (Energy) Energy cost (electricity, natural gas, other) affect the } \\
\text { (cost) of product and service }\end{array}$ \\
\hline & $\begin{array}{l}\text { (Energy) The cost of energy conservation program affects the } \\
\text { cost of product and service }\end{array}$ \\
\hline & $\begin{array}{l}\text { (Solid wastes) Cost of disposing and recycling solid wastes } \\
\text { affects the organization profitability. }\end{array}$ \\
\hline & $\begin{array}{l}\text { The ecological foot print impact can enhance the financial } \\
\text { profitability ratios (ROI, ROA, ROE....etc.) }\end{array}$ \\
\hline
\end{tabular}

\section{Description of the proposed model}

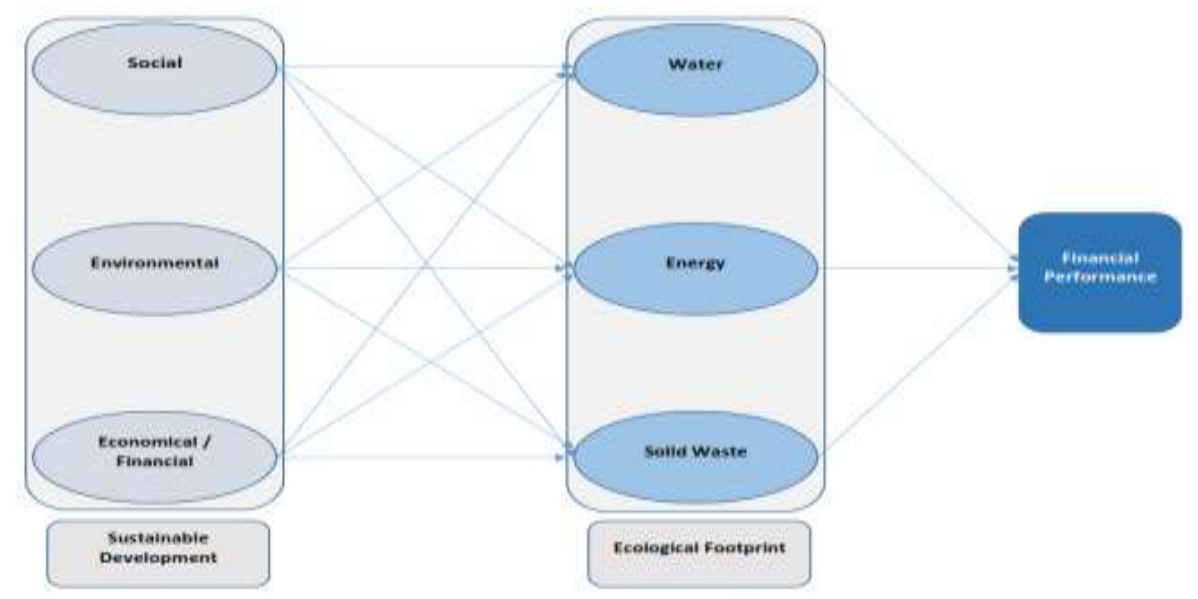

Figure (1): proposed Ecological footprint model

The environmental issues may present themselves as temporary or permanent change to the atmosphere, water, and land due to tourist 
activities, which can result in impacts that may either reversible or irreversible. The social issues may emerge in the workplace of a client's operations and also may impact the surrounding communities. A tourist's performance in the areas listed below can present environmental and social risk to the operation:

- Water use and conservation (tourist's operations use water in various production processes, which vary from place to another. Typically, water use at the facility level is associated with different activities.)

- Wastewater and water quality (tourist's operations generate wastewater, which is treated on site and/or discharged either to the municipal sewage system for treatment or directly to the environment (surface water) without prior treatment.)

- Energy use and conservation (A tourist's consumptions energy to power processes such as heating and cooling; auxiliary systems such as motors, pumps and fans; generating compressed air; heating, ventilation and air conditioning systems (HVAC); lighting systems.)

- Solid wastes (tourist's operations may generate, store, or handle any quantity of hazardous or non-hazardous waste across a range of industry sectors. Hazardous materials are materials that represent a risk to human health, property, or the environment due to their physical or chemical characteristics like water supply treatment plant, or air pollution control facility and other discarded materials including solid, liquid, and semi-solid. Or non-hazardous like any garbage, food waste, refuse, sludge from a wastewater treatment plant)

The Economic/Financial performance of the firm play a pivotal role in environmental management system. Many hotel managers suggest that profitability is hurt by the higher production costs of environmental management activities, while others cite that there is a positive evidence of increased profitability. The proposed model suggests a positive links between the environmental management associated with decreasing the ecological footprint to improving the financial performance of the hotels. The linkage to firm performance will be tested empirically using archival data of firm-level environmental and financial performance. Both practitioners and researchers can link between environmental 
management and financial performance; this can be used as a measure of the benefits experienced by industry leaders.

\section{Guidelines for new model implementation:}

Therefore, the appropriate way to enhance the service industry is to implement the new model with its proposed three folds constructs by the practitioners to achieve its ultimate goal, which is environmental conservation. The next guidelines are a good starting point for the service business by delivering:

- Benchmark or developing a stable standard for measuring the actual consumption of water used during different level of occupation at the selected hotels. Then compare the actual consumption with the ecological footprint standards to reduce wastewater and work to improve water quality in order to take action and correct the deviations or find way to reduce the consumption and increase water conservation. Finally, measuring the effectiveness of the action taken on hotel profitability.

- Likewise, for energy conservation, practitioners must analyse the ecological footprint standards to understand and measure the key drivers or the close link between the energy use and energy conservation. Then, find ways to reduce tourists' consumptions of energy with its different forms, like heating and cooling; fans; ventilation and air conditioning systems and lighting systems, etc. to give a clear evidence of how can these activities affect hotel profitability.

- As for the solid wastes and the huge quantity produced by the tourists at the hotels, hoteliers must find way to control this wastes either hazardous or non-hazardous wastes by comparing the quantity produced with the ecological footprint standards. There is no universally applicable set of principles or rules by which to manage and control the solid wastes at the hotels as most of them use the segregation system. Hotel chains are individually different, face different situations, and require different ways of managing. Therefore, controlled experiments give better results and for sure each chain search for ways to increase the profitability.

- Look over the economies of scale by concentrating on the competitive advantages and the unique selling proposition to differentiate the marketing offering and answer the question why 
hotels apply environmental conservation techniques and ignore nonenvironmental techniques. Therefore, hotels must capture the opportunities to improve the financial profitability ratios (ROI, ROA, ROE....etc.) while keeping the overall hotels budget constant.

\section{Data analysis}

The Factor Analysis as a technique was employed to the answers of respondents pertaining the construct. Confirmatory Factor Analysis was used to verify the proposed model construction and operationalization. In this case, the scale was specified upfront as appears above in figure (5) and (6) and it was known that a certain subset of the scale represents an independent dimension within this scale. For example, it is known that the questions pertaining to "noticeable management practices regarding the utilization of available resource during crisis time: are: forced employee downsizing, lower number of employee training and development programmes, lower employee benefits, lower quality of food and beverage items, and lower prices, undesirable market segments. If there is a need to build a regression model that predicts the influence of the previous elements on an outcome variable, in this case "employee major concerns and behavioural patterns during crisis times" we would start to model a confirmatory factor analysis of the questionnaire items that load onto the above highlighted elements and then regress onto an outcome variable.

An exploratory factor analysis was also employed. The data collection instruments of this study consist of a lot of questions that represent 12 clusters (variables). Exploratory Factor Analysis attempted to bring intercorrelated variables together under more general, underlying variables. More specifically, the goal of this type of factor analysis is to reduce the dimensionality of the original space and to give an interpretation to the new space, spanned by a reduced number of new dimensions which are supposed to underlie the old ones.

\section{Results and discussion}

Descriptive analysis was used initially in order to show the means, standard deviation and coefficient of variation of the target sample under 
study for the three folds environmental, social and economic/financial. Table (2) shows reliability and intrinsic validity for research variables. Table (3) presents descriptive statistics for social. Table (4) provides the descriptive statistics for environmental. Table (5) shows the descriptive statistics for economic/financial. Table (6) Confirmatory Factor Analysis by standardized and unstandardized regression weights. Table (7) shows the Goodness of Fit Indices in the Confirmatory Factor Analysis. Finally, table (8) provides the Full Entry logistic regression model to determine effect of Ecological footprint accounting model to Assess the Financial performance of Hospitality Industry in Egypt.

The objective of this research study is to integrate the Ecological footprint accounting model with the three pillars of sustainable development in Egyptian five star hotels and to measure financial performance of the hospitality industry in Egypt based on the Ecological Footprint proposed model. The model is introducing new layers of depth measure to the effect of the ecological footprint and the sustainable development on the social, environmental and financial performance of the five star hotels. The model is opening new thinking channels that urge managers to deal with a sustainable development as an opportunity to generate more profits and financial gains to hospitality properties. The employed data collection instrument had few questions that aim at exploring and evaluating the current situation within the hospitality industry in Egypt.

\section{1- Reliability and intrinsic validity for research variables:}

Table (2): Reliability and intrinsic validity for research variables

\begin{tabular}{|c|l|c|c|}
\hline No & \multicolumn{1}{|c|}{ Dimension } & $\begin{array}{c}\text { Reliability } \\
\text { coefficient }\end{array}$ & $\begin{array}{c}\text { intrinsic } \\
\text { validity }\end{array}$ \\
\hline 1 & Social. & 0.840 & 0.9165 \\
\hline 2 & Environmental. & 0.877 & 0.9364 \\
\hline 3 & Economic/Financial. & 0.893 & 0.9449 \\
\hline \multicolumn{2}{|c|}{ Total } & 0.949 & 0.9741 \\
\hline
\end{tabular}

According to Table (2), we find out that reliability coefficient and intrinsic validity for research dimensions are (0.949), (0.9741) respectively; highly internal consistency based on the average inter-item correlation. The most four dimensions with highly Reliability coefficients are: Economic/Financial, Environmental, and Social, with Reliability coefficient $(0.893),(0.877),(0.840)$ respectively. 


\section{Social:}

Table (3): Descriptive statistics for Social

\begin{tabular}{|c|c|c|c|c|c|}
\hline NO. & Statements & MEAN & $\mathrm{SD}$ & $\mathrm{CV}$ & RANK \\
\hline 1 & $\begin{array}{l}\text { (Water) Employees using tap } \\
\text { water in their daily activities } \\
\text { for serving guests }\end{array}$ & 4.1321 & 0.64845 & 15.69 & 1 \\
\hline 2 & $\begin{array}{l}\text { (Water) Health Safety } \\
\text { Environment (HSE) } \\
\text { programs for measuring } \\
\text { water quality (affect the } \\
\text { activities of organization) }\end{array}$ & 4.1226 & 0.71318 & 17.30 & 2 \\
\hline 3 & $\begin{array}{l}\text { (Energy) Employees using } \\
\text { only electricity in all } \\
\text { working activities for } \\
\text { serving guests (cooking, } \\
\text { heating, lighting, and } \\
\text { transportation) }\end{array}$ & 3.9057 & 0.73715 & 18.87 & 3 \\
\hline 4 & $\begin{array}{l}\text { (Energy) Employees using } \\
\text { other sources of energy } \\
\text { rather than electricity in } \\
\text { working activities (natural } \\
\text { gas, gasoline, coal...etc) }\end{array}$ & 3.7642 & 0.81125 & 21.55 & 4 \\
\hline 5 & $\begin{array}{l}\text { (Solid wastes) Volume of } \\
\text { solid waste generated by } \\
\text { employees and guest affects } \\
\text { daily activates }\end{array}$ & 3.7642 & 0.85693 & 22.77 & 5 \\
\hline & TOTAL & 3.9377 & .59096 & 15.01 & -- \\
\hline
\end{tabular}

According to Descriptive statistics in table (3), it can be concluded that:

- the most three homogeneous variables are: Employees using tap water in their daily activities, admit your shortcomings, Health Safety Environment, and Employees using only electricity in all working activities with coefficient of variation (15.69\%), (17.30\%), (18.87\%) respectively.

While the value of total weighted mean for Social is (3.9377), with coefficient of variation $\mathbf{( 1 5 . 0 1 \% )}$, therefore we have sometimes direction to the Social dimension. 


\section{Environmental:}

Table (4): Descriptive statistics for Environmental

\begin{tabular}{|c|c|c|c|c|c|}
\hline NO. & Statements & MEAN & $\mathrm{SD}$ & $\mathrm{CV}$ & RANK \\
\hline 1 & $\begin{array}{l}\text { (Water) The organization using } \\
\text { efficient methods to reduce } \\
\text { water pollution (reuse, } \\
\text { recycle....) }\end{array}$ & 3.9340 & 0.69377 & 17.64 & 1 \\
\hline 2 & $\begin{array}{l}\text { (Water) The organization using } \\
\text { efficient methods to rationalize } \\
\text { the use of water }\end{array}$ & 4.0283 & 0.74906 & 18.59 & 2 \\
\hline 3 & $\begin{array}{l}\text { (Energy) The organization } \\
\text { using different techniques to } \\
\text { decrease the volume of energy } \\
\text { used }\end{array}$ & 3.8585 & 0.76144 & 19.73 & 3 \\
\hline 4 & $\begin{array}{l}\text { (Energy) Some of the energy } \\
\text { used by the organization come } \\
\text { from renewable resources } \\
\text { (solar, wind, others) }\end{array}$ & 3.6887 & 0.78514 & 21.29 & 4 \\
\hline 5 & $\begin{array}{l}\text { (Solid wastes) The organization } \\
\text { using effective program to } \\
\text { reduce the volume of solid } \\
\text { waste (ISO 14001) }\end{array}$ & 3.7170 & 0.80184 & 21.57 & 5 \\
\hline 6 & $\begin{array}{l}\text { (Solid wastes) The organization } \\
\text { segregates the solid waste at } \\
\text { the source }\end{array}$ & 3.6226 & 0.86688 & 23.93 & 6 \\
\hline & $\begin{array}{c}\text { TOTAL } \\
\end{array}$ & 3.8082 & 0.61196 & 16.07 & -- \\
\hline
\end{tabular}

According to Descriptive statistics in table (4), it can be concluded that:

- The most three homogeneous variables are: The organization using efficient methods to reduce water pollution, the organization using efficient methods to rationalize the use of water, and The organization using different techniques to decrease the volume of energy used, with coefficient of variation $(17.64 \%),(18.59 \%)$, $(19.73 \%)$ respectively.

- While the value of total weighted mean for Social is (3.8082), with coefficient of variation $(\mathbf{1 6 . 0 7 \%})$, therefore we have sometimes direction to the Environmental dimension. 


\section{Economic / Financial:}

Table (5): Descriptive statistics for Economic / Financial

\begin{tabular}{|c|c|c|c|c|c|}
\hline NO. & Statements & MEAN & SD & $\mathrm{CV}$ & RANK \\
\hline 1 & $\begin{array}{l}\text { (Water) Tap water cost } \\
\text { affects the cost of product } \\
\text { and service provided to } \\
\text { customer. }\end{array}$ & 3.9333 & 0.72413 & 18.41 & 5 \\
\hline 2 & $\begin{array}{l}\text { (Water) The cost of } \\
\text { wastewater disposal affects } \\
\text { profitability. }\end{array}$ & 4.0381 & 0.73280 & 18.15 & 2 \\
\hline 3 & $\begin{array}{l}\text { (Water) The cost of water } \\
\text { treatments } \\
\text { profitability }\end{array}$ & 3.9905 & 0.74026 & 18.55 & 6 \\
\hline 4 & $\begin{array}{l}\text { (Water) The cost of water } \\
\text { quality enhancement affects } \\
\text { profitability, (filtering, } \\
\text { treatment, etc.). }\end{array}$ & 3.9238 & 0.71650 & 18.26 & 4 \\
\hline 5 & $\begin{array}{l}\text { (Energy) Energy cost } \\
\text { (electricity, natural gas, } \\
\text { other) affect the (cost) of } \\
\text { product and service }\end{array}$ & 3.6952 & 0.76112 & 20.60 & 7 \\
\hline 6 & $\begin{array}{l}\text { (Energy) The cost of energy } \\
\text { conservation program affects } \\
\text { the cost of product and } \\
\text { service }\end{array}$ & 3.9623 & 0.64623 & 16.31 & 1 \\
\hline 7 & $\begin{array}{l}\text { (Solid wastes) Cost of } \\
\text { disposing and recycling solid } \\
\text { wastes affects the } \\
\text { organization profitability. }\end{array}$ & 3.8962 & 0.80391 & 20.63 & 8 \\
\hline 8 & $\begin{array}{l}\text { The ecological foot print } \\
\text { impact can enhance the } \\
\text { financial profitability ratios ( } \\
\text { ROI, ROA, ROE....etc) }\end{array}$ & 3.9717 & 0.72319 & 18.21 & 3 \\
\hline & TOTAL & 3.9262 & 0.55489 & 14.13 & -- \\
\hline
\end{tabular}

According to Descriptive statistics in table (5), it can be concluded that:

- The most three homogeneous variables are: The cost of energy conservation program, The cost of waste water disposal affects profitability., and The ecological foot print impact can enhance the financial profitability ratios (ROI, ROA, ROE....etc), with 
coefficient of variation (16.31\%), (18.15\%), (18.21\%) respectively. While the value of total weighted mean for Social is (3.9262), with coefficient of variation $(\mathbf{1 4 . 1 3} \%)$, therefore we have sometimes direction to the Social dimension.

\section{3- Confirmatory Factor Analysis (CFA):}

The confirmatory factor analysis is conducted to test how well the measured variables represent the constructs. The key advantage is that the researcher can analytically test a conceptually grounded theory explaining how different measured items represent important business measures. When CFA results are combined with construct validity tests, the researcher can obtain a better understanding of the quality of their measures.

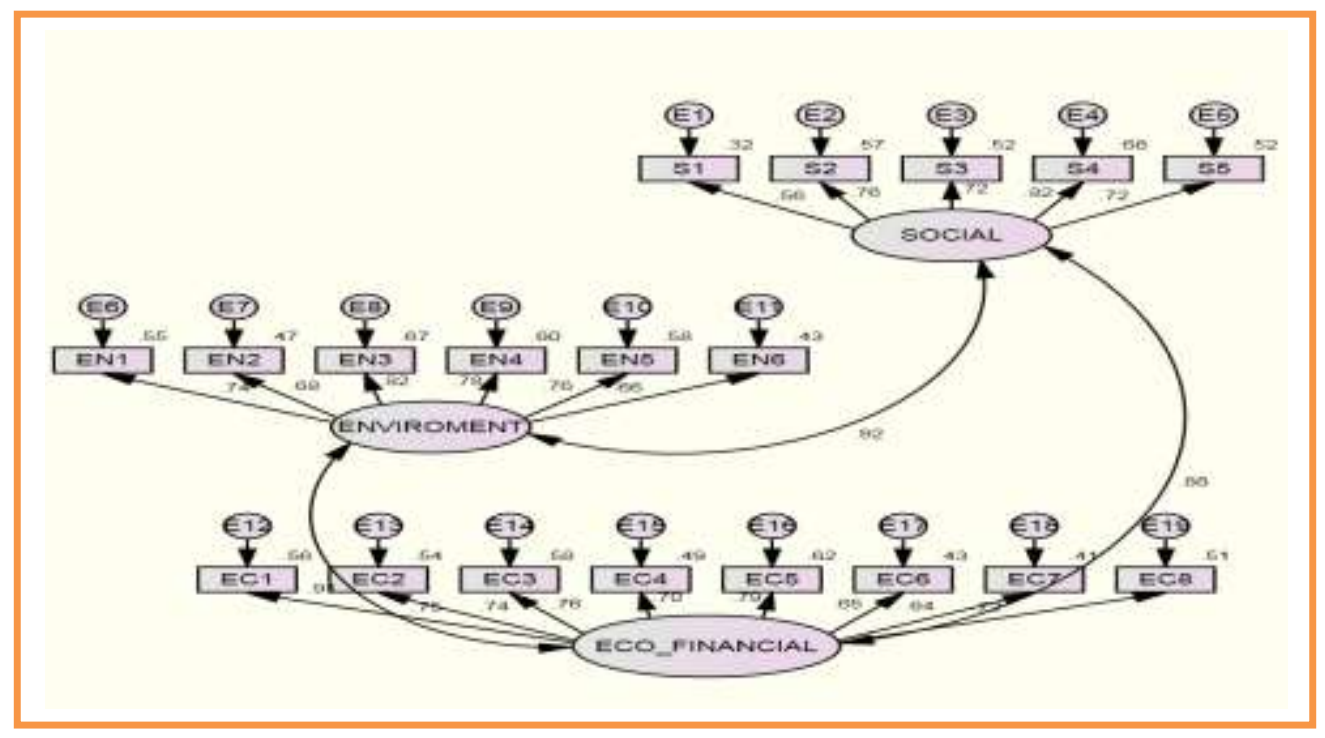

Figure (2): Confirmatory factor analysis results (path diagram for a

measurement model)

Table (6) shows the three constructs which were initially considered to express the effect of Ecological footprint accounting model to Assess the Financial performance of Hospitality Industry in Egypt. The construct validity is the extent to which a set of measured items actually measures the construct. This has been computed in the Confirmatory Factor Analysis and variables shown in the table (6) were found to be valid. 
Table (6): Confirmatory Factor Analysis by standardized and unstandardized regression weights

\begin{tabular}{|c|c|c|c|c|c|c|}
\hline & & $\begin{array}{c}\text { Standardize } \\
\mathrm{d} \\
\text { estimate }\end{array}$ & $\begin{array}{l}\text { Unstandardiz } \\
\text { ed estimate }\end{array}$ & S.E. & $\underset{t}{t \_t e s}$ & $\begin{array}{l}\text { Signific } \\
\text { ant level }\end{array}$ \\
\hline S1 & $<--$ SOCIAL & 1.000 & 0.564 & & & \\
\hline S2 & $<--$ SOCIAL & 1.475 & 0.757 & .258 & 5.713 & $0.001 * * *$ \\
\hline S3 & $<--$ SOCIAL & 1.453 & 0.721 & .262 & 5.551 & $0.001 * * *$ \\
\hline S4 & <--- SOCIAL & 1.825 & 0.823 & .305 & 5.991 & $0.001 * * *$ \\
\hline S5 & $<--$ SOCIAL & 1.688 & 0.721 & .304 & 5.549 & $0.001 * * *$ \\
\hline EN1 & <--- ENVIROMENT & 1.000 & 0.745 & & & \\
\hline EN2 & <--- ENVIROMENT & .991 & 0.684 & .141 & 7.039 & $0.001 * * *$ \\
\hline EN3 & <--- ENVIROMENT & 1.204 & 0.817 & .141 & 8.561 & $0.001 * * *$ \\
\hline EN4 & <--- ENVIROMENT & 1.181 & 0.778 & .146 & 8.104 & $0.001 * * *$ \\
\hline EN5 & <--- ENVIROMENT & 1.181 & 0.761 & .149 & 7.916 & $0.001 * * *$ \\
\hline EN6 & <--- ENVIROMENT & 1.103 & 0.658 & .163 & 6.750 & $0.001 * * *$ \\
\hline $\mathrm{EC} 1$ & \begin{tabular}{|l|l|}
--- & ECO_FINANCIA \\
\end{tabular} & 1.000 & 0.746 & & & \\
\hline $\mathrm{EC} 2$ & \begin{tabular}{|l|l|}
--- & ECO_FINANCIA \\
\end{tabular} & 1.001 & 0.736 & .131 & 7.624 & $0.001 * * *$ \\
\hline $\mathrm{EC} 3$ & $<$\begin{tabular}{l|l|}
$<--$ & ECO_FINANCIA \\
\end{tabular} & 1.046 & 0.762 & .132 & 7.920 & $0.001 * * *$ \\
\hline $\mathrm{EC} 4$ & $<$\begin{tabular}{l|l|} 
ECO_FINANCIA \\
$\mathrm{L}$
\end{tabular} & .925 & 0.697 & .129 & 7.176 & $0.001 * * *$ \\
\hline EC5 & \begin{tabular}{|l|l|} 
& ECO_FINANCIA \\
$\mathrm{L}$
\end{tabular} & 1.109 & 0.790 & .135 & 8.233 & $0.001 * * *$ \\
\hline EC6 & \begin{tabular}{|l|l|} 
& ECO_FINANCIA \\
$\mathrm{L}$
\end{tabular} & .780 & 0.653 & .116 & 6.694 & $0.001 * * *$ \\
\hline $\mathrm{EC} 7$ & \begin{tabular}{l|l}
$<---$ & ECO_FINANCIA \\
$\mathrm{L}$
\end{tabular} & .950 & 0.640 & .145 & 6.542 & $0.001 * * *$ \\
\hline $\mathrm{EC} 8$ & $<-<\mid \begin{array}{l}\text { ECO_FINANCIA } \\
\mathrm{L}\end{array}$ & .957 & 0.716 & .129 & 7.395 & $0.001 * * *$ \\
\hline
\end{tabular}

*** Significant at level less than (0.001).

According to Table (6), the researchers can conclude the following:

1. All standardized regression weights (factor loading) are greater than 0.50 -which means that all measured variables are statistically significant. 
2. t- Test for all measured variables is significant at a level of significance less than $(0.001)$ respectively.

3. The significant linear positive relationship among the three latent variables; social, environmental, and economic/financial have coefficient values with (0.924), (0.880), and (0.913) at Significant at level less than (0.001).

\section{4- Measuring the Goodness of Fit of the (CFA) model:}

Table (7): The Goodness of Fit Indices in the Confirmatory Factor Analysis

\begin{tabular}{|l|c|}
\hline Chi-Square & 268.756 \\
\hline Degree of Freedom & 149 \\
\hline Level of Significance & 0.001 \\
\hline Normed Chi-Square & 1.804 \\
\hline Root Mean Square Residual (RMR) & 0.036 \\
\hline Goodness of Fit Index (GFI) & 0.772 \\
\hline Adjusted Goodness of Fit Index (AGFI) & 0.710 \\
\hline Normed Fit Index (NFI) & 0.804 \\
\hline Relative Fit Index (RFI) & 0.775 \\
\hline Incremental Fit Index (IFI) & 0.902 \\
\hline Tucker Lewis Index (TLI) & 0.885 \\
\hline Comparative Fit Index (CFI) & 0.900 \\
\hline Root Mean Square Residual Approximation (RMSEA) & 0.087 \\
\hline The mean variance extracted & 0.56 \\
\hline
\end{tabular}

From table 7, the researchers noticed the following:

1. All the goodness of fit tests of the model showed significant results or i.e., the majority of indicators at acceptable limits, and then the possibility of matching the actual form of the model estimated.

2. The mean variance extracted for all latent constructs is 0.56 i.e., there is adequate convergent validity

\section{5- The logistic regression model}

There are many important research topics for which the dependent variable is "limited." or categorical response variable. Logistic regression is useful for situations in which you want to be able to predict the presence or absence of a characteristic or outcome based on values of a set of predictor variables. It is similar to a linear regression model but is 
suited to models where the dependent variable is dichotomous. Logistic regression coefficients can be used to estimate odds ratios for each of the independent variables in the model. Logistic regression is applicable to a broader range of research situations than discriminant analysis.

Table (8): Full Entry logistic regression model to determine effect of Ecological footprint accounting model to Assess the Financial performance of Hospitality Industry in Egypt

\begin{tabular}{|c|c|c|c|c|c|c|c|c|}
\hline \multirow{2}{*}{$\begin{array}{l}\mathbf{N} \\
\mathbf{o}\end{array}$} & \multirow{2}{*}{$\begin{array}{c}\text { Independent } \\
\text { Variables }\end{array}$} & \multirow{2}{*}{$\begin{array}{c}\text { Estimate } \\
\text { d } \\
\text { coefficie } \\
\text { nt }\end{array}$} & \multicolumn{2}{|c|}{ Wald test } & \multicolumn{2}{|c|}{ Chi -square test } & \multirow[b]{2}{*}{$\mathbf{R}^{2}$} & \multirow[t]{2}{*}{ Prob. } \\
\hline & & & value & Sig. & value & Sig. & & \\
\hline $\begin{array}{l}1 \\
2 \\
3 \\
4\end{array}$ & $\begin{array}{l}\text { Constant } \\
\text { Social } \\
\text { Environmental } \\
\text { Economic , } \\
\text { Financial }\end{array}$ & $\begin{array}{l}2.02- \\
2.019 \\
1.757 \\
1.545\end{array}$ & $\begin{array}{l}263.30 \\
14.333 \\
26.959 \\
28.267\end{array}$ & $\begin{array}{l}* * * 0.001 \\
* * * 0.001 \\
* * * 0.001 \\
* * * 0.001\end{array}$ & 63.67 & $* * * 0.001$ & $83.6 \%$ & $\begin{array}{l}0.86 \\
0.99 \\
0.93\end{array}$ \\
\hline
\end{tabular}

* Parameter is significant at the (.05) level

** Parameter is significant at the (.001) level

****Parameter is significant at the (.001) level

According to Stepwise multiple logistic regression model in table (8), it can be concluded the following:

\section{1- Chi-square test:}

The chi-square statistic is the change in the $-2 \log$-likelihood from the previous step, block, or model. Use the "Model Chi-Square" statistic to determine if the overall model is statistically significant, Like F test in linear regression model, since The value of "chi square test" is (28.973) with significant at the $(0.001)$ level, then the researcher concludes that the overall independent variables statistically significant impact on the dependent variable or the model is fitted to logistic regression.

\section{2- The Classification table:}

The classification table helps you to assess the performance of your model by cross tabulating the observed response categories with the predicted response categories. For each case, the predicted response is the category treated as 1 , if that category's predicted probability is greater than the user-specified cutoff. Cells on the diagonal are correct predictions, whereas Cells off the diagonal are incorrect predictions.

\section{3- Coefficient of determination:}


The Independent Variables accepted in the model explain (83.6\%) from total variation of $\log$ odds ratio or logit model,i.e., dependent variable, Financial performance of Hospitality Industry in Egypt, the rest percent due to either the random error in the regression model or other Independent Variables excluded from regression model. Larger pseudo rsquare statistics indicate that more of the variation is explained by the model, to a maximum of 1 .

\section{4- Wald test:}

It would be useful in determining the significant value of each of the individual independent variables coefficient in the logistic regression model. The ratio of B to S.E., squared, equals the Wald statistic. If the Wald statistic is significant (i.e., less than 0.05) then the parameter is useful to the model. The significant independent variables are: Social, Environmental, and Economic / Financial, with significant at less than (0.05), (0.001) level respectively.

\section{5- Probability event:}

The Probability event of each independent variable is the odds ratio divided by Odds ratio plus one, then the important variables are Return on equity and Institutional ownership with probabilities (0.86) (0.99), and (0.93) respectively.

\section{6- Logistic Regression model:}

$$
\left[P(Y)=\left[1+e^{-(-2.202+2.019 \text { Soc }+1.757 \text { Env }+1.545 \text { Eco } / \text { Fin })}\right]^{-1}\right]
$$

By substituting the values of independent variables, we can then predict the dependent variable: financial performance of the hotels.

\section{CONCLUSION}

Sustainable development asks that social and economic needs are also accounted for within the accounting reporting framework. In many instances, hospitality also has negative social and cultural impacts in destinations, and economic benefits may not be evenly distributed. Nevertheless, hospitality undoubtedly has great potential to support economic development and is an important element of many countries' economies. It also has the potential to inform people about sustainable development and conservation within their economy. 
The results of the paper are to be considered among the first publication to link the ecological footprint model with an accounting measures within the hospitality industry in Egypt. The research showed the importance of reporting the assurance reports about the impact of environmental, economic and social factors on the resources of the companies within a special emphasis on the Egyptian hospitality industry. The research also, contributed to the literature by providing a proposed model that included proposed measures for the different variables of the ecological footprint concept from the accounting point of view and validated its application the Egyptian environment.

The researchers concluded the following:

- The sustainable development has a positive impact on the environmental performance of the hospitality industry in Egypt.

- The validity of the proposed model measures in reflecting the impact of sustainable development on the financial performance in the hospitality industry.

- The explanation power of the proposed measures is very high as $\mathrm{R}^{2}$ is $84 \%$ of the variability of the sustainability of the hotels.

- The three constructs which were initially considered to express the effect of ecological footprint accounting model to assess the financial performance of hospitality industry in Egypt are valid with potentiality of improvements in future researches to consider the other variables not included in the research.

\section{REFERENCES}

- Ahmad, Y., El Serafy, S. and Lutz, E. (Eds) (1989), Environmental Accounting for Sustainable Development, The World Bank, Washington, D.C.

- Almeida-Neto, M., Guimaraes, P., Guimarães, P. R., Loyola, R. D., \& Ulrich, W. (2008). A consistent metric for nestedness analysis in ecological systems: reconciling concept and measurement. Oikos, 117(8), 1227-1239.

- Bebbington, J. and Larrinaga, C. (2014), "Accounting and sustainable development: an exploration", Accounting, Organizations and Society, Vol. 39 No. 6. 
- Böhler, S., Grischkat, S., Haustein, S., \& Hunecke, M. (2006). Encouraging environmentally sustainable holiday travel. Transportation Research Part A: Policy and Practice, 40(8), 652670.

- Budeanu, A., Miller, G., Moscardo, G., \& Ooi, C. S. (2016). Sustainable tourism, progress, challenges and opportunities: an introduction. Journal of Cleaner Production, 111, 285-294.

- Cartamil, D. P., Vaudo, J. J., Lowe, C. G., Wetherbee, B. M., \& Holland, K. N. (2003). Diel movement patterns of the Hawaiian stingray, Dasyatis lata: implications for ecological interactions between sympatric elasmobranch species. Marine Biology, 142(5), 841-847.

- Cerutti, A. K., Beccaro, G. L., Bruun, S., Donno, D., Bonvegna, L., \& Bounous, G. (2016). Assessment methods for sustainable tourism declarations: The case of holiday farms. Journal of Cleaner Production, 111, 511-519.

- Claire Gillet-Monjarret, (2018) "Assurance reports included in the CSR reports of French firms: alongitudinal study", Sustainability Accounting, Management and Policy Journal, Vol. 9 Issue: 5, pp. 570-594

- Coscieme, L., Pulselli, F. M., Niccolucci, V., Patrizi, N., \& Sutton, P. C. (2016). Accounting for "land-grabbing" from a biocapacity viewpoint. Science of The Total Environment, 539, 551-559.

- Diamantis, D., \& Ladkin, A. (1999). The links between sustainable tourism and ecotourism: a definitional and operational perspective. Journal of Tourism Studies, 10(2), 35.

- Fernández, M., Alférez, A., Vidal, S., Fernández, M. Y., \& Albareda, S. (2016). Methodological approaches to change consumption habits of future teachers in Barcelona, Spain: reducing their personal Ecological Footprint. Journal of Cleaner Production.

- Fortier, J., \& Messier, C. (2006). Are chemical or mechanical treatments more sustainable for forest vegetation management in the context of the TRIAD?. The forestry chronicle, 82, 806-818.

- Galli, A. (2015). On the rationale and policy usefulness of Ecological Footprint Accounting: The case of Morocco. Environmental Science \& Policy, 48, 210-224. 
- Genovart, M., Arcos, J. M., Álvarez, D., McMinn, M., Meier, R., B. Wynn, R., \& Oro, D. (2016). Demography of the critically endangered Balearic shearwater: the impact of fisheries and time to extinction. Journal of Applied Ecology.

- Gibassier, D. (2018). Corporate Water Accounting, Where Do We Stand? The International Water Accounting Field and French Organizations. In Sustainability Accounting: Education, Regulation, Reporting and Stakeholders (pp. 31-65).

- Gössling, S., Hansson, C. B., Hörstmeier, O., \& Saggel, S. (2002). Ecological footprint analysis as a tool to assess tourism sustainability. Ecological economics, 43(2), 199-211.

- Hart, D. D., Johnson, T. E., Bushaw-Newton, K. L., Horwitz, R. J., Bednarek, A. T., Charles, D. F., \& Velinsky, D. J. (2002). Dam Removal: Challenges and Opportunities for Ecological Research and River Restoration We develop a risk assessment framework for understanding how potential responses to dam removal vary with dam and watershed characteristics, which can lead to more effective use of this restoration method. BioScience, 52(8), 669682.

- Holland, L. (2003). Can the principle of the ecological footprint be applied to measure the environmental sustainability of business?. Corporate Social Responsibility and Environmental Management, 10(4), 224-232.

- Hunter, C. (2002). Sustainable tourism and the touristic ecological footprint. Environment, development and sustainability, 4(1), 720.

- Hunter, C., \& Shaw, J. (2007). The ecological footprint as a key indicator of sustainable tourism. Tourism management, 28(1), 4657.

- Kasim, A. (2015). Environmental management system (EMS) Postulating the value of its adoption to organizational learning in hotels. International Journal of Contemporary Hospitality Management, 27(6), 1233-1253.

- Kitzes, J., Galli, A., Bagliani, M., Barrett, J., Dige, G., Ede, S., \& Jolia-Ferrier, L. (2009). A research agenda for improving national Ecological Footprint accounts. Ecological Economics, 68(7), 1991-2007. 
- Koocheki, A., Nassiri Mahallati, M., \& Khorramdel, S. (2016). Ecological Foodprint of Iran. Agroecology and Sustainable Food Systems.

- Lele, S. M. (1991). Sustainable development: a critical review. World development, 19(6), 607-621.

- Maroun, W., \& Atkins, J. (2018). The emancipatory potential of extinction accounting: Exploring current practice in integrated reports. In Accounting Forum (Vol. 42, No. 1, pp. 102-118). Elsevier.

- Martin, H. A. (1997). The use of ecological tolerances for the reconstruction of Tertiary palaeoclimates. Australian Journal of Botany, 45(3), 475-492.

- Melissen, F., van Ginneken, R., \& Wood, R. C. (2016). Sustainability challenges and opportunities arising from the owner-operator split in hotels. International Journal of Hospitality Management, 54, 35-42.

- Mock, T.J., Rao, SS. and Srivastava, RP. (2013), "The development of worldwide sustainability reporting assurance", Australian Accounting Review, Vol. 23 No. 4, pp. 280-294.

- Murphy, P. E., \& Price, G. G. (2005). Tourism and sustainable development. On line publications 167.

- Nakajima, E. S., \& Ortega, E. (2016). Carrying capacity using energy and a new calculation of the ecological footprint. Ecological Indicators, 60, 1200-1207.

- O'Dwyer, B. and Owen, D.L. (2005), “Assurance statement practice in environmental, social and sustainability reporting: a critical evaluation", The British Accounting Review, Vol. 37 No. 2, pp. 205-229.

- Ozturk, I., Al-Mulali, U., \& Saboori, B. (2016). Investigating the environmental Kuznets curve hypothesis: the role of tourism and ecological footprint. Environmental Science and Pollution Research, 23(2), 1916-1928.

- Parayil, G. (1996). The 'Kerala model' of development: development and sustainability in the Third World. Third World Quarterly, 17(5), 941-958.

- Patterson, T. M., Niccolucci, V., \& Bastianoni, S. (2007). Beyond "more is better": ecological footprint accounting for tourism and 
consumption in Val di Merse, Italy. Ecological Economics, 62(3), 747-756.

- Pezzey, J., Rusong, W., Hinman, G. W., Ruitenbeek, H. J., Kairiukstis, L., Buracas, A., ... \& Neugebauer, B. (1990). Economic analysis of sustainable growth and sustainable development (No. P01 P522 SM-AMPO). Banco Mundial, Washington, DC (EUA).

- Rees, W. E. (2000). Eco-footprint analysis: merits and brickbats. Ecological Economics, 32(3), 371-374.

- Rees, W., \& Wackernagel, M. (1996). Urban ecological footprints: why cities cannot be sustainable - and why they are a key to sustainability. Environmental impact assessment review, 16(4), 223-248.

- Rotzek, J. N., Scope, C., \& Günther, E. (2018). What energy management practice can learn from research on energy culture?. Sustainability Accounting, Management and Policy Journal.

- Samanthi Silva, Edeltraud Guenther, (2018) "Setting the research agenda for measuring sustainability performance - systematic application of the world café method", Sustainability Accounting, Management and Policy Journal, Vol. 9 Issue: 4, pp.455-469

- Senbel, M., McDaniels, T., \& Dowlatabadi, H. (2003). The ecological footprint: a non-monetary metric of human consumption applied to North America. Global Environmental Change, 13(2), 83-100.

- Sigee, D. C., Glenn, R., Andrews, M. J., Bellinger, E. G., Butler, R. D., Epton, H. A. S., \& Hendry, R. D. (1999). Biological control of cyanobacteria: principles and possibilities. In The Ecological Bases for Lake and Reservoir Management (pp. 161-172). Springer Netherlands.

- Toth, G., \& Szigeti, C. (2016). The historical ecological footprint: From over-population to over-consumption. Ecological Indicators, 60, 283-291.

- Wackernagel, M., \& Yount, J. D. (2000). Footprints for sustainability: the next steps. Environment, Development and Sustainability, 2(1), 23-44.

- Wackernagel, M., Onisto, L., Bello, P., Linares, A. C., Falfán, I. S. L., Garcia, J. M. \& Guerrero, M. G. S. (1999). National natural 
capital accounting with the ecological footprint concept. Ecological economics, 29(3), 375-390.

- Wackernagel, M., Schulz, N. B., Deumling, D., Linares, A. C., Jenkins, M., Kapos, V. \& Randers, J. (2002). Tracking the ecological overshoot of the human economy. Proceedings of the national Academy of Sciences, 99(14), 9266-9271.

- Welford, R., Ytterhus, B., \& Eligh, J. (1999). Tourism and sustainable development: an analysis of policy and guidelines for managing provision and consumption. Sustainable Development, 7(4), 165. 